\title{
South African government continues policy of inactivity
}

During an opening ceremony more akin to that seen at sporting events than scientific conferences, and one that was screened on national television and punctuated by commercial breaks, the President of South Africa, Thabo M beki, failed to acknowledge the magnitude of the HIV/AIDS problem that blights his country when he addressed attendees and members of the general public at the XIIIth International AIDS Conference in Durban last month. More than 4.2

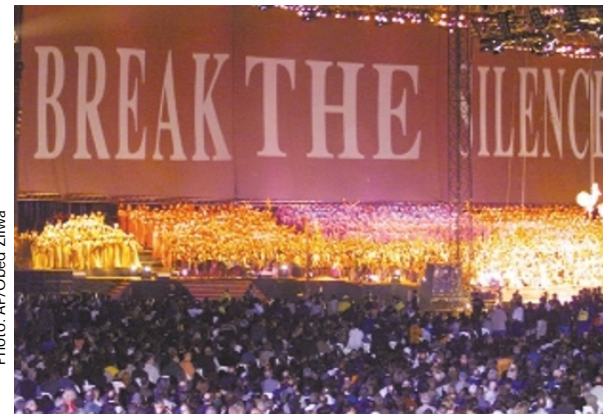

XIII ${ }^{\text {th }}$ World AIDS Conference opening ceremony million South Africans are infected and the country is expected to experience negative population growth by 2003.

Mbeki's speech had been eagerly awaited by both orthodox and dissident scientists alike following his decision to create a presidential panel combining the two factions to examine whether HIV is the cause of AIDS (Nature 405, 105; 2000). Although he used the phrase "HIV/AIDS" seven times, he ducked the opportunity to end the widely held perception that he personally sides with dissidents in believing HIV does not cause AIDS. While his speech was well received by a few South African scientists, it was described as utterly disappointing by researchers from other countries.

M beki devoted the first 5 of his 15minute talk addressing what he called "the real killer" in Africa, poverty, and re turned to this theme at the end of his speech. Before addressing AIDS, he spoke at length of the devastation caused by polio, leprosy, measles and starvation. He then proceeded to defend his right to assemble the HIV discussion panel by saying he felt the need to be better informed about the disease. He angered many with his statement, "there is no substance to the allegation that there is any hesitation on the part of our government to confront the challenge of HIV-AIDS."

Anthony Fauci, director of the US National Institute for Allergy and Infectious Diseases told Nature Medicine that he was deeply disappointed that the president had spoken in such generic terms about the health threat facing the country. "This disease is spreading expoence. Orthodox scientists nentially in this country," said Fauci, "and M beki missed the window of opportunity to tackle it." Fauci was saddened that the president did not address specific issues such as mother-to-child-transmis-

sion (MTCT), and what the likely response of the government might be to Boehringer Ingelheim's offer-made prior to thestart of the conference-to provide nevirapine free of charge for a five-year

period for the prevention of MTCT of HIV in developing countries. Neither did Mbeki mention his government's policy of refusing to give AZT to pregnant women and rape victims.

Fauci's thoughts echoed the disgust of many attendees who felt that M beki's establishment of the AIDS panel was merely wasting time and that he had largely dodged the issue of HIV/AIDS in his speech. However, William Makgoba, president of the South African Medical Research Council, felt that the speech had been positive because, he believes, it shows that the president no longer questions the link between HIV and AIDS.

Makgoba served on the presidential AIDS panel that concluded its business at a second meeting held in Pretoria prior to the conferfrom the panel are confident that the issue has been laid to rest, but in one small victory for the dissidents, panel mem-

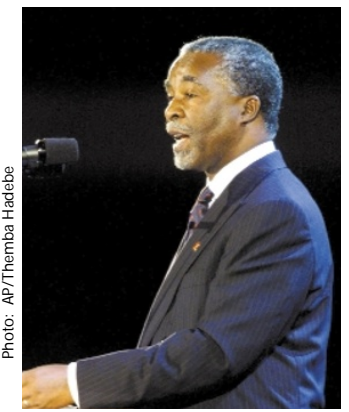

President Thabo Mbeki
The day after Mbeki's speech, the South African Minister of Health, Manto Tshabalala-Msimang held a press briefing and announced, "The president of this country has never denied either the existence of AIDS nor this causal connection between HIV and AIDS." In response to questions of action on MTCT, she said her government had supported research in South Africa on AZT and nevirapine and that she welcomed discussion of these data.

Unsurprisingly, the data, which were presented at the Durban conference, confirm results gathered in the US and Uganda. Daya Moodley of the University of Natal Medical School reported data from the 'SAINT' trial that concluded that nevirapine is as effective as an AZT/3TC combination in preventing MTCT in South African women and children.

Based on the South African data, Director-General of the Department of Health, Ayanda N tsaluba seemed quietly confident that nevirapine would now be approved for MTCT in the country. However, Tshabalala-Msimang commented that she will "be looking at the recommendations of the WHO on this matter." This leads many to fear that she will draw upon the controversial WHO document on anti-retroviral drug use in the Third World released in March, which states that although scientific evidence that a single dose of the drug nevirapine prevents MTCT, there is "currently insufficient information" to recommend its wide-scale implementation (Nature Med 6, 726; 2000).

Finally, Tshabalalabers have agreed to confirm the reliability of diagnostic tests for HIV. The study will be coordinated by Makgoba, Helen Gayle the Director of the Centers for Disease Control and Prevention's National Center for HIV, STD, and TB Prevention, and AIDS dissident Harvey Bialey of the Autonomous National University of Mexico. The country's HIV surveillance system is also to be reexamined. The panel is preparing a report on their discussions due out by year-end.
Msimang reiterated her government's policy of denouncing AIDS drugs used in the West by rejecting "the notion that simply defines the adequacy of national responses to the issue of provision of antiretroviral drugs. These simplistic applications that are insensitive to the North /South realities are ridiculous to say the least." She was one of 14 African ministers to criticize Boehringer for making its drug offer public before discussing the matter with governments.

Karen Birmingham, Durban 